\title{
Differences in Effectiveness of Clogs and Captive Path Games to Improve Gross Motor Skills in Children 4-5 Years
}

\author{
Ruth Eka Mudji Setiawaty ${ }^{1 *}$, Eko Darminto1, Miftakhul Jannah \\ ${ }_{1}^{1}$ Postgraduate of State University of Surabaya, Surabaya, Indonesia \\ ruth.17070855085@mhs.unesa.ac.id \\ *Corresponding Author
}

How to Cite : Setiawaty, R., E., M., Darminto, E., Jannah, M. (2020). Differences in Effectiveness of Clogs and Captive Path Games to Improve Gross Motor Skills in Children 4-5 Years. International Journal for Educational and Vocational Studies, 2 (1), 1- 4. DOI: https://doi.org/10.29103/ijevs.v2i1.2261

\section{ARTICLE HISTORY}

Received:13 October 2019

Revised: 27 November 2019

Accepted: 25 December 2019

\section{KEYWORDS}

Clogs game;

Captive Path game;

Gross motor skills;

Children aged 4-5

\begin{abstract}
This study aims to determine (1) Effective Clogs game to improve gross motor skills of children aged 4-5 years. (2) Captive Path game is effective in increasing the gross motor skills of children aged 4-5 years (3) There is a difference in the effectiveness of the game of Clogs and Captive Path increases the gross motor abilities of children aged $4-5$ years. This research uses a quantitative research design. The analysis of the results of the study was carried out using the parametric statistical approach, which required a normality test, a homogeneity test, and to determine differences in the hypothesis, a T-test was performed on the $\mathrm{N}$-gain score. The results showed that: (1) based on the normality test, the values for pre-test and post-test were greater than 0.05 , so the clogs had normal distribution data. Homogeneity test results in pre-test and post-test values greater than 0.05 , so clogs have homogeneous data. (2) based on the normality test, the values for the pre-test and post-test are greater than 0.05 , then the captive path game has normally distributed data. (3) Based on the T-test on the N-gain Score, the sig value $<0.05$ for clogs games concluded that clogs games effectively improve the gross motor skills of children aged $4-5$ years while for captive path game produces sig values $>0.05$ concluded that the game of captivity ineffective in increasing gross motor skills of children aged $4-5$ years.
\end{abstract}

This is an open access article under the CC-BY-SA license.

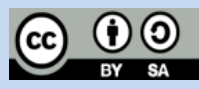

\section{INTRODUCTION}

Early childhood learning is oriented to laying fundamentals or bases towards the growth and development of physical, language, cognitive, social-emotional, artistic, moral values and all other intelligences (plural intelligences). Children aged 4-6 years are categorized as early childhood and are also referred to as preschool children. Institutions that organize early childhood education must be able to accommodate all aspects of child development in a pleasant atmosphere so as to generate interest and the child is interested in doing the learning by itself. The learning process that takes place is interesting, involves students and is carried out vigorously will have a significant influence on children's learning efforts. Educators must design and implement learning activities as effectively and efficiently as possible in order to bring maximum results. For children, play is their world and has a very important role. Some psychologists write their opinions that play activities can be a means to optimize early childhood development. According to Pica (2011: 58) space outside the classroom must be used for play activities that enhance physical motor skills and other abilities as well as children's emotional, creativity, and cognitive abilities. Games as a method of learning can be done so that children are trained in motor skills. Likewise cognitive and social abilities will also develop in tandem. Opportunity to play and learn outdoors is important for the development of a healthy child as a whole (Frost, 2017: 82). In short, a pleasant game will affect the physical growth and development of the soul later.

Early childhood educators play an important role in providing opportunities for children to do activities outside the classroom as part of daily learning (Wirth, 2012: 43). Broad knowledge is needed for educators to continue to explore their abilities in choosing games that are creative, innovative, right on target, full of meaning 
and must remain enjoyable. This is a big problem for educators.

Gross motor development is very important for early childhood. The presumption that gross motor skills will develop automatically with increasing age is false. Gross motor development in early childhood requires help from educators. How gross physical motor activities that please children, the types of games that are appropriate to the level of their age development, and how the games are done that can motivate children is something that should be prepared by an educator.

Each learning activity should have a positive impact on children's development so that the weaknesses that arise can be anticipated. Learning given in a game should be conducive to the formation of attitudes, positive and creative ways of thinking in order to shape the soul of leadership and social skills. These skills are the ability to overcome all problems that arise as a result of interactions with the social environment and the ability to present themselves in accordance with applicable rules and norms. In this case the educator must be able to choose a game that has the ability to stimulate a child's motor development.

Mutiah (2010: 91) believes that play is a very important activity for children's growth and development. The experience of playing and studying outdoors in urban areas is not prioritized by adults, causing disruption to the optimal locomotor ability of children (Sisson, 2017: 8). The method of learning with clogs and captive path game is an activity with physical activity that is fun, grouped, and has an enormous impact on early childhood growth and development. The level of difficulty that exists in the game is very possible to do observation and evaluation activities on children's motor skills. From the description above, a study with the title "Differences in Effectiveness of Clogs and Captive Path Games to Improve the Gross Motor Ability of Children 4-5 Years".

Starting from the background of the above problems, a number of problems can be formulated as follows: (1) Are clogging games effective in increasing the gross motor skills of children aged 4-5 years? (2) Are prisoner paths game effective in increasing the gross motor skills of children aged 4-5 years? (3) Are there differences in the effectiveness of clogs and prisoner paths game to improve the gross motor skills of children aged 4-5 years?.

\section{METHODS}

This research is quantitative research. by using the experimental method in the control and experimental groups. This study provides treatment for subjects or a group of subjects whose aim is to find out whether there is a difference in effectiveness of the treatment that has been given to the variable. This research is the independent variable clogs game (X1) and captive path game (X2), while the dependent variable is gross motor ability (Y). The population in this study were all children aged 4-5 years at TK Lintang and Taman Sari, Surabaya. The sample to be taken was divided into two classes, namely the experimental class and the control class, which amounted to 42 children

The instruments used in this study were the grating of the development instrument, the development rubric, and the observation guidelines. The starting point of the preparation of the instrument lattice is to determine the indicators taken from the Standard of Child Development Achievement Levels listed in the 2013 curriculum. observations that will be used for data collection in this study.

The research data were analyzed using the parametric statistical approach, the T-test. To calculate numerical data using parametric statistics, it is necessary to test the assumptions first as requirements for normality and homogeneity. Next to find out the difference in effectiveness, an $\mathrm{N}$-gain test is performed.

\section{RESULTS AND DISCUSSION}

The normality test results using the Kolmogorov Smirnov formula of clogs on the initial observation of the experimental group 0.094, the final observation of 0.073 . The initial observation of the control group was 0.200 , the final observation was 0.176 . All of these values are greater than 0.05 so it can be concluded that clogs have normal distribution data. While the results of the normality test use the Kolmogorov Smirnov formula of captive path game at the initial observation of the experimental group 0.200 , the final observation of 0.200 . The initial observation of the control group was 0.200 and the final observation was 0.200. All of these values are greater than 0.05 so it can be concluded that the game of captivity has normally distributed data.

\begin{tabular}{|c|c|c|c|c|c|}
\hline \multicolumn{6}{|c|}{ One-Sample Kolmogorov-Smirnov Test } \\
\hline & & $\begin{array}{l}\text { Pre Clog } \\
\text { Control }\end{array}$ & \begin{tabular}{|l} 
Post Clog \\
Control
\end{tabular} & \begin{tabular}{|l|} 
Pre Clog \\
Experiment
\end{tabular} & $\begin{array}{l}\text { Post Clog } \\
\text { Experiment }\end{array}$ \\
\hline \multicolumn{2}{|l|}{$\mathrm{N}$} & 21 & 21 & 21 & 21 \\
\hline \multirow{2}{*}{$\begin{array}{l}\text { Normal } \\
\text { Parameters }\end{array}$} & Mean & 17.8571 & 18.5714 & 18.1905 & 24.8095 \\
\hline & Std. Deviation & 2.47560 & 2.15804 & 2.08852 & 1.74983 \\
\hline \multirow{3}{*}{$\begin{array}{l}\text { Most Extreme } \\
\text { Differences }\end{array}$} & Absolute & .159 & .155 & .175 & .180 \\
\hline & Positive & .159 & .148 & .139 & .135 \\
\hline & Negative & -140 & -.155 & -.175 & -.180 \\
\hline \multicolumn{2}{|l|}{ Test Statistic } & .159 & .155 & .175 & .180 \\
\hline \multicolumn{2}{|c|}{ Asymp. Sig. (2-tailed) } & $.176^{c}$ & $.200^{c d}$ & $.094^{c}$ & $.073^{c}$ \\
\hline \multicolumn{6}{|c|}{ a. Test distribution is Normal. } \\
\hline \multicolumn{6}{|c|}{ b. Calculated from data. } \\
\hline \multicolumn{6}{|c|}{ c. Lilliefors Significance Correction. } \\
\hline
\end{tabular}




\begin{tabular}{|c|c|c|c|c|c|}
\hline \multicolumn{6}{|c|}{ One-Sample Kolmogorov-Smirnov Test } \\
\hline & & \begin{tabular}{|l|} 
Pre Captive \\
Path Control
\end{tabular} & \begin{tabular}{|l|} 
Post Captive \\
Path Control
\end{tabular} & $\begin{array}{l}\text { Pre Captive Path } \\
\text { Experiment }\end{array}$ & \begin{tabular}{|l|} 
Post Captive \\
Path Experiment
\end{tabular} \\
\hline \multicolumn{2}{|l|}{$\mathrm{N}$} & 21 & 21 & 21 & 21 \\
\hline \multirow{2}{*}{$\begin{array}{l}\text { Normal } \\
\text { Parametersa.b }\end{array}$} & Mean & 17.7619 & 18.2381 & 17.8095 & 19.5238 \\
\hline & Std. Deviation & 2.54764 & 2.71854 & 2.46209 & 2.61952 \\
\hline \multirow{3}{*}{$\begin{array}{l}\text { Most Extreme } \\
\text { Differences }\end{array}$} & Absolute & .143 & .121 & .105 & .118 \\
\hline & Positive & .136 & .121 & .105 & .118 \\
\hline & Negative & -.143 & -.107 & -.099 & -.113 \\
\hline \multicolumn{2}{|l|}{ Test Statistic } & .143 & .121 & .105 & .118 \\
\hline \multicolumn{2}{|c|}{ Asymp. Sig. (2-tailed) } & $.200^{c d}$ & $.200^{\mathrm{cd}}$ & $.200^{\mathrm{cd}}$ & $.200^{\mathrm{cd}}$ \\
\hline \multicolumn{6}{|c|}{\begin{tabular}{|l} 
a. Test distribution is Normal. \\
\end{tabular}} \\
\hline \multicolumn{6}{|c|}{ b. Calculated from data. } \\
\hline \multicolumn{6}{|c|}{ c. Lilliefors Significance Correction. } \\
\hline \multicolumn{6}{|c|}{ d. This is a lower bound of the true significance. } \\
\hline
\end{tabular}

Homogeneity test on the game of clogs for pre-test resulted in a value of 0.316 and post-test of 0.227 . Based on the established criteria, the value is greater than the 0.05 significance so that the data from clogs in this study are homogeneous. Whereas the homogeneity test results in the captive path game for pre-test amounted to 0.697 and post-test amounted to 0.930. Based on predetermined criteria, the value is greater than the significance of 0.05 so that the game of captive path in this study is homogeneous.

\begin{tabular}{|c|c|c|c|c|c|}
\hline \multicolumn{6}{|c|}{ Test of Homogeneity of Variances } \\
\hline & & $\begin{array}{l}\text { Levene } \\
\text { Statistic }\end{array}$ & $d f 1$ & $d f 2$ & Sig. \\
\hline \multirow{4}{*}{$\begin{array}{l}\text { pre Clog } \\
\text { game }\end{array}$} & Based on Mean & 1.030 & 1 & 40 & .316 \\
\hline & Based on Median & .572 & 1 & 40 & .454 \\
\hline & $\begin{array}{l}\text { Based on Median and with } \\
\text { adjusted df }\end{array}$ & .572 & 1 & $\begin{array}{l}39.4 \\
08\end{array}$ & .454 \\
\hline & Based on trimmed mean & 1.029 & 1 & 40 & .316 \\
\hline \multirow{4}{*}{$\begin{array}{l}\text { post Clog } \\
\text { game }\end{array}$} & Based on Mean & 1.458 & 1 & 40 & .234 \\
\hline & Based on Median & 1.210 & 1 & 40 & .278 \\
\hline & $\begin{array}{l}\text { Based on Median and with } \\
\text { adjusted df }\end{array}$ & 1.210 & 1 & $\begin{array}{l}37.8 \\
20\end{array}$ & .278 \\
\hline & Based on trimmed mean & 1.506 & 1 & 40 & .227 \\
\hline
\end{tabular}

\begin{tabular}{|c|c|c|c|c|c|}
\hline \multicolumn{6}{|c|}{ Test of Homogeneity of Variances } \\
\hline & & $\begin{array}{l}\text { Levene } \\
\text { Statistic }\end{array}$ & $d f 1$ & $d f 2$ & Sig. \\
\hline \multirow{4}{*}{$\begin{array}{l}\text { pre captive } \\
\text { path game }\end{array}$} & Based on Mean & .177 & 1 & 40 & .676 \\
\hline & Based on Median & .118 & 1 & 40 & .733 \\
\hline & $\begin{array}{l}\text { Based on Median and with } \\
\text { adjusted df }\end{array}$ & .118 & 1 & 39.911 & .733 \\
\hline & Based on trimmed mean & .153 & 1 & 40 & .697 \\
\hline \multirow{4}{*}{$\begin{array}{l}\text { Post captive } \\
\text { path game }\end{array}$} & Based on Mean & .007 & 1 & 40 & .932 \\
\hline & Based on Median & .011 & 1 & 40 & .916 \\
\hline & $\begin{array}{l}\text { Based on Median and with } \\
\text { adjusted df }\end{array}$ & .011 & 1 & 39.963 & .916 \\
\hline & Based on trimmed mean & .008 & 1 & 40 & .930 \\
\hline
\end{tabular}

\section{Group Statistics}

\begin{tabular}{|l|l|r|r|r|r}
\hline \hline NGain Dercen & group & \multicolumn{1}{|c|}{$\mathrm{N}$} & Mean & Std. Deviation & Std. Error Mean \\
\hline & $\begin{array}{l}\text { Clog } \\
\text { game }\end{array}$ & 21 & 69.2179 & 11.76065 & 2.56638 \\
\hline $\begin{array}{l}\text { Captive } \\
\text { Path } \\
\text { game }\end{array}$ & 21 & $18.10 / 1$ & 8.12323 & $1.1 / 263$ \\
\hline
\end{tabular}

N-gain effectiveness category according to Arikunto (2010)

\begin{tabular}{|c|c|}
\hline Percentage (\%) & Interpretation \\
\hline 440 & Ineffective \\
\hline $40-55$ & Less Effective \\
\hline $56-75$ & Effective Enough \\
\hline 76 & Effective \\
\hline
\end{tabular}

The first hypothesis test obtained by the T-test results known sig (2-tailed) value of $0,000<0.05$, then as a basis for decision making in the T-test it was concluded that $\mathrm{HO}$ is rejected and accept Ha which means that clogs are effective for increasing the gross motor skills of children 4-5 years. The second hypothesis test obtained sig (2-tailed) value of $0.126>0.05$, then as a basis for decision making in the t test it was concluded that $\mathrm{Ha}$ is rejected and accepts $\mathrm{H} 0$ which means that captive path game is ineffective in improving the gross motor skills of children aged 4-5 years. This $\mathrm{N}$-gain test is performed to calculate the categorization of the effectiveness of clogs and captive path game to improve the gross motor skills of children aged 4-5 years. The calculation result of the average $\mathrm{N}$-gain score of clogs shows a value of $69.2179 \%$ which is included in the category of quite effective (56-76\%) according to the interpretation of the effectiveness of the gain index according to Arikunto so that it can be said that clogs are effective enough to improve children's gross motor skills age 4-5 years. As for the results of the calculation of the average $\mathrm{N}$-gain score of captive road games showed a value of $18,1071 \%$ which is included in the ineffective category $(<40 \%)$ according to the interpretation of the effectiveness of the gain index according to Arikunto so that it can be said that captive path game is not effective to improve the ability gross motor skills of children aged 4-5 years.

\section{CONCLUSION}

It was found the effectiveness of clogs in improving gross motor skills of children aged 4-5 years in Tegalsari sub-district, Surabaya. Clogs have a high enough effectiveness based on data that has been carried out according to research procedures. T-test results of captive path game showed no effectiveness in improving the gross motor skills of children aged 4-5 years in Tegalsari 
sub-district, Surabaya. There is a difference in effectiveness between clogs and captive path game in improving gross motor skills of children aged 4-5 years in Tegalsari sub-district of Surabaya, where clogs are more effective than captive path game.

\section{REFERENCES}

Arikunto, S. (2010). Prosedur Penelitian Suatu Pendekatan Praktik. Jakarta: Rineka Cipta

Frost, J. L. \& Sutterby, J.A. (2017). Outdoor Play Is Essential to Whole Child Development. NAEYC Journal Article. 72(3), 82-85. Retrieved from https://www.jstor.org/stable/90013690

Fadlilah, M. (2017). Buku Ajar Bermain dan Permainan Anak Usia Dini, Jakarta: Prenada Media Group.

Fujii, H. \& Kojiri, T. (2017). Advice-Sharing Environment for Acquiring Motor Skills. Science Direct Elsevier.122,1954-1963. https://doi: 10.1016/j.procs.2017.08.066

Galdi, M. D’Anna, C. Pastena, N. \& Paloma, F. G. (2015). Gross-motor skills for potential intelligence descriptive study in a kindergarten. Science Direct Elsevier.174, 3797-3804. https://doi: 10.1016/j.sbspro.2015.01.1115.

Laely, K. (2017). Pengaruh Permainan Bakiak Terhadap Peningkatan Kecerdasan Motorik Kasar Anak Usia Dini. Jurnal PAUD, ISSN 2407-9189 Tahun 2017, Universitas Muhammadiyah Magelang. Journal.ummgl.ac.id https:///1559-Article\%20Text-3655-1-10-2017110 9.pdf

McMlelland, M. M. \& Cameron, C. E. (2017). Developing Together: The role of Executive Function and Motor Skills in Children's Early Academic Lives. Early Childhood Research Quarterly 46.. 142-151. https://doi: 10.1016/j.ecresq.2018.03.014

Najafabadi, M. G. Sheikh,M.Hemayattalab,R. Memari, A. H. Aderyani, M. R. \& Hafisi, S. (2017). The Effect of SPARK on social and motor skills of children with autism. Science Direct Taiwan Pediatric Association. 59, 481-487. https://doi: 10.1016/j.pedneo.2017.12.005

Oberer, N. Gashaj, V. \& Roebers, C. M. (2018). Executive Functions, Visual Motor Coordination, Physical Fitness and Academic Achievement: Longitudinal Relations in Typically Developing Children. Human Movement Science Elsevier. 58, 69-79. https://doi:10.1016/j.humov.2018.01.003.

Pica,R. (2011). Taking Movement Education Outdoors. NAEYC Journal Article. 66(4), 58-59. Retrieved from: https://www.jstor.org/stable/42731281

Pratiwi, Niken. (2019). Kegiatan Belajar 4: Fisik Motorik dan Seni Anak Usia Dini. Modul 3 PPG-Konten Kurikulum. Diunduh dari: http://docplayer.info/84696823-Kegiatan-belajar- 4-fisik-motorik-dan-seni-anak-usia-dini-niken-pr atiwi-m-pd.html

Sisson, J. H. \& Lash, M. (2017). Outdoor Learning Experiences Connecting Children to Nature: Perspectives from Australia and United States. NAEYC Journal Article. 72(4), 8-16. Retrieved from https://www.jstor.org/stable/90013699

Webster, E. K. Martin, C. K. \& Staiano, A. E. (2018). Fundamental motor skills, screen-time, and physical activity in preschoolers. Science Direct Elsevier. Journal of Sport and Health Science.00, 1-8. https://doi: 10.1016/j.jshs.2018.11.006

Wirth,S. \& Rosenow,N. (2012). Supporting Whole-Child Learning in Nature-Filled Oudoor Classrooms. NAEYC Journal Article. 67(1), 42-48. Retrieved from https://www.jstor.org/stable/42731125 